\title{
ANALISIS SEBARAN KLOROFIL- $\alpha$ DAN KUALITAS AIR DI EKOSISTEM SEKITAR PT KAYU LAPIS INDONESIA (PANTAI, MUARA, TAMBAK) KALIWUNGU KENDAL
}

\author{
Siti Widya Arfiatin, Agung Suryanto, Max Rudolf Muskananfola ${ }^{I}$ \\ Program Studi Manajemen Sumberdaya Perairan, Jurusan Perikanan \\ Fakultas Perikanan dan Ilmu Kelautan, Universitas Diponegoro
}

\begin{abstract}
ABSTRAK
PT. Kayu Lapis Indonesia yang terletak di kawasan pesisir muara Sungai Wakak telah banyak merubah fungsi ekosistem. Kegiatan yang dilakukan oleh PT KLI akan berdampak bagi kawasan pesisir, baik bagi lingkungan maupun masyarakat perikanan sekitarnya. Salah satu indikator kesuburan perairan adalah ketersediaan klorofil- $\alpha$ di perairan. Untuk mengetahui tingkat kesuburan perairan, perlu dilakukan analisis sebaran klorofil- $\alpha$ dan kualitas airnya. Penelitian ini bertujuan untuk mengetahui tingkat kesuburan perairan yakni sebaran klorofil- $\alpha$ dan kualitas air serta hubungan klorofil- $\alpha$ dengan kualitas air di perairan sekitar PT. Kayu Lapis Indonesia. Penelitian ini dilaksanakan pada bulan Maret, April dan Mei 2013. Pengambilan sampel dilakukan dua kali dalam sebulan yakni pada saat pasang dan surut. Metode yang digunakan dalam penelitian ini adalah purposive sampling. Pengambilan sampel air dilakukan di tiga ekosistem yaitu tambak, muara dan pantai. Variabel yang diukur secara in situ meliputi kecerahan, suhu, salinitas, arus. Pengukuran klorofil- $\alpha$, nitrat dan fosfat dilakukan di laboratorium. Analisis data menggunakan ANOVA (analysis of varians) dengan Microsoft Excell. Selanjutnya, menggunakan analisis regresi berganda untuk mengetahui hubungan antara klorofil- $\alpha$ dengan kualitas air dan analisis korelasi untuk mengetahui keeratan hubungan tersebut. Hasil penelitian menunjukkan bahwa konsentrasi klorofil- $\alpha$ dan kualitas air secara keseluruhan menunjukkan perairan sekitar PT. KLI berada pada tingkat kesuburan yang rendah atau oligotrofik. Analisis ragam (ANOVA) dua arah diperoleh Fhitung lebih kecil dari Ftabel yang berarti terima Ho menunjukkan sebaran klorofil-a dan kualitas air tidak terjadi perbedaan secara nyata secara spasial sedangkan secara temporal diperoleh Fhitung lebih besar dari Ftabel yang berarti tolak Ho yang menunjukkan terjadi perbedaan secara nyata antar waktu. Analisis korelasi regresi menunjukkan adanya hubungan yang kuat antar klorofil- $\alpha$ dengan variabel nitrat, fosfat dan kecerahan yang terjadi pada ekosistem pantai dengan nilai koefisien korelasi (r) terbesar 0,95 dan koefisien determinasi $\left(\mathrm{R}^{2}\right)$ sebesar 0,92 yang berarti sebesar $92 \%$ variabel $\mathrm{X}$ (nitrat, fosfat, kecerahan) mempengaruhi variabel Y (klorofil- $\alpha$ ).
\end{abstract}

Kata kunci : Klorofil-a, kualitas air, perairan sekitar PT Kayu Lapis Indonesia

\section{ABSTRACT}

PT. Kayu Lapis Indonesia that located in the Wakak estuary has altered many ecosystem functions. Activities undertaken by PT. KLI will impact coastal areas, both on environment and the surrounding fisheries communities. One indicator of water productivity is the availability of chlorophyll-a. To determine the level of water productivity, it is necessary to analyze the distribution of chlorophyll-a and water quality. This study aims to determine the level of waters productivity through distribution of chlorophyll-a and water quality and relationship of chlorophyll-a to water quality in the waters around PT. Kayu Lapis Indonesia. This study was conducted on March, April and May 2013. Sampling was conducted twice a month at high tide and low tide. The method used in this research was purposive sampling. Water sampling conducted in three ecosystems i.e ponds, estuaries and coastal. Variables measured in-situ include brightness, temperature, salinity, currents. Measurement of chlorophyll-a, nitrate and phosphate were conducted at the Aquatic Resource Management's laboratory. Data analysis using two-way ANOVA (analysis of variance) with Microsoft Excell. Then, the relationship and corellation of chlorophyll-a and water quality were analysed using multiple regression and correlation analysis. The results showed that the concentrations of chlorophylla and water quality in overall around PT. KLI water's in low level of productivity or oligotrophik. Two-way analysis of variance (ANOVA) obtained $\mathrm{F}$ value smaller than $\mathrm{F}$ table which means accept Ho that shows distribution of chlorophyll-a and water quality does not happen in real difference, while the temporal spatial obtained $\mathrm{F}$ value greater than $\mathrm{F}$ table which means reject Ho that showed there was a difference in between real time. Regression correlation analysis showed a strong relationship between chlorophyll- $\alpha$ with variable nitrate, phosphate and brightness that occur on coastal ecosystems with the largest a correlation coefficient (r) of 0.95 and the coefficient of determination (R2) of 0.92 , which means by $92 \%$ variable $\mathrm{X}$ (nitrate, phosphate, brightness) affects variable Y (chlorophyll- $\alpha$ ).

Keywords : Chlorophyl-a, water quality, coastal water of PT Kayu Lapis Indonesia

1) Penulis Penanggungjawab 


\section{Pendahuluan}

PT. Kayu Lapis Indonesia (KLI) adalah salah satu perusahaan penebangan dan pemrosesan kayu terbesar di Indonesia. Pabrik yang terletak di kawasan pesisir Kendal ini telah banyak memberikan perubahan terhadap ekosistem sekitar. Menurut warga sekitar, beberapa perubahan yang terjadi antara lain ditandai dengan pembelokan sungai, abrasi pantai dan hilangnya tambak sekitar ekosistem. Hilangnya tambak pembudidaya menyebabkan penurunan pendapatan pada masyarakat perikanan budidaya.

Berdasarkan uraian diatas, maka perlu diadakan penelitian untuk mengetahui tingkat kesuburan perairan serta kualitas airnya. Pentingnya informasi mengenai tingkat kesuburan perairan sekitar setelah adanya kegiatan industri oleh PT. KLI dapat digunakan sebagai pengelolaan wilayah pesisir secara terpadu. Salah satu indikator kesuburan perairan adalah ketersediaan klorofil-a di perairan. Menurut Clark (1977) dalam Sanusi (2004), tingkat kesuburan suatu perairan pesisir dapat dinilai dari karakteristik biologi maupun kimianya, khususnya ketersediaan zat hara esensial. Menurut Nybakken (1992) dalam Astuti (2008), faktor biologis yang mempengaruhi tingkat kesuburan suatu perairan adalah klorofil-a. Klorofil-a merupakan pigmen yang mampu melakukan fotosintesis dan terdapat di seluruh organisme fitoplankton.

Kualitas suatu perairan dipengaruhi tinggi rendahnya pasokan nutrien dari darat. Nutrien yang terdapat di suatu perairan biasanya berbentuk N dan P. Clark (1977) dalam Sanusi (2004) mengemukakan bahwa nitrat dan fosfat merupakan nutrien utama yang dibutuhkan bagi pertumbuhan organisme fitoplankton (produktivitas primer). Menurut Febrianty (2011), nutrien yang masuk ke perairan dapat mempengaruhi kualitas air di perairan tersebut. Sedangkan Faizal, et al. (2011) mengatakan bahwa tingkat kesuburan perairan laut sangat terkait dengan tingginya konsentrasi nutrien dalam kolom air.

Penelitian ini bertujuan untuk mengetahui sebaran spasial dan temporal klorofil-a dan kualitas air di ekosistem sekitar PT. Kayu Lapis Indonesia serta keterkaitan antara kandungan klorofil-a dengan kualitas air untuk melihat tingkat kesuburan perairan ekosistem sekitar PT. Kayu Lapis Indonesia. Manfaat penelitian ini yaitu untuk pengelolaan potensi sumberdaya perairan di sekitar PT. KLI Kendal melalui hasil analisis tingkat kesuburan perairan dengan indikator sebaran klorofil-a dan kualitas air (suhu, kecerahan, arus, salinitas, nitrat dan fosfat).

\section{Materi dan Metode Penelitian}

A. Materi Penelitian

Materi yang digunakan dalam penelitian ini adalah sampel air yang di ambil dari ekosistem pantai, tambak dan muara sekitar PT. KLI, Kaliwungu, Kendal. Sampel air ini akan dianalisis kandungan klorofil-a, nitrat dan fosfat. Beberapa kualitas air yang diukur untuk mendukung penelitian ini meliputi suhu, kecerahan, kedalaman, arus dan salinitas.

Alat-alat yang digunakan pada penelitian ini meliputi termometer air raksa yang digunakan untuk mengukur suhu aur dan udara; secchi disk digunakan untuk mengukur kecerahan dan kedalaman; currentmeter digunakan untuk mengukur kecepatan arus; refraktometer digunakan untuk mengukur salinitas; $\mathrm{pH}$ paper digunakan untuk mengukur $\mathrm{pH}$; coolbox digunakan untuk menyimpan sampel air; botol sampel gelap digunakan sebagai wadah untuk mengambil sampel air; spektrofotometer digunakan untuk mengukur kandungan klorofil-a; sentrifuge digunakan untuk mencampur sampel klorofil-a; hach spektrofotometer digunakan untuk mengukur nitrat dan fosfat; vacum pump digunakan untuk menyaring sampel klorofil; filtering flask digunakan untuk menampung hasil penyaringan sampel klorofil; corong digunakan untuk menyaring sampel air; botol reaksi digunakan untuk tempat sampel yang akan diukur pada spektrofotometer.

Bahan-bahan yang digunakan pada penelitian ini meliputi es batu yang digunakan untuk mengawetkan sampel air pada coolbox; aceton digunakan untuk mengekstrak sampel klorofil; kertas saring Whatman digunakan untuk menyaring sampel klorofil; reagen nitra ver 5 digunakan untuk analisa nitrat; reagen phos ver 3 digunakan untuk analisa fosfat; aquades digunakan untuk kalibrasi; dan air sampel digunakan untuk analisa klorofil, nitrat dan fosfat.

\section{B. Metode Penelitian}

Metode penelitian yang digunakan adalah studi kasus, yaitu suatu metode penelitian yang merupakan bagian dari penelitian deskriptif, merupakan suatu bentuk penelitian, yang ditujukan untuk mendeskripsikan atau menggambarkan fenomena-fenomena yang ada, baik itu fenomena almiah atau fenomena yang direkayasa manusia (Sukmadinata, 2007). Metode sampling digunakan purposive sampling, yaitu metode yang menentukan titik sampling berdasarkan pertimbangan penelitinya (Sudjana, 2005).

Teknik pengumpulan data dilakukan dengan pendekatan sampling survey method, yaitu pengumpulan data dengan mencatat sebagian kecil dari populasi namun hasil yang diperoleh diharapkan dapat menggambarkan sifat populasi yang menjadi objek penelitian (Purwanto dan Dyah, 2007). Metode survey ini merupakan metode yang secara kuantitatif bisa menentukan generalisasi (pengambilan keputusan atau kesimpulan secara umum) bagi keadaan lingkungan atau populasi yang dipelajari (Sudjana, 2005). Alasan pemilihan metode ini karena areal pesisir yang luas sehingga tidak mungkin diteliti secara keseluruhan karena terkait tenaga, waktu dan biaya. 


\section{Penentuan lokasi sampling}

Penentuan lokasi sampling dilakukan setelah survey pendahuluan. Pemilihan lokasi sampling berdasarkan pendugaan dampak dari kegiatan PT. KLI secara langsung. Setelah survey pendahuluan dilakukan, ditentukan tiga ekosistem yakni pantai, muara dan tambak. Ekosistem pantai terdiri dari 3 titik, 2 titik berada di sebelah barat dan timur kayu lapis dan 1 titik lainnya berada di utara kayu lapis. Ekosistem muara terdiri dari 3 titik, titik 1 dekat dengan laut dan 2 titik berikutnya berada tepat di sebelah timur PT. KLI. Ekosistem tambak juga terdiri dari tiga titik yaitu titik 1 terdapat pada tambak yang terkena dampak langsung PT. KLI dan 2 titik berikutnya yang tidak terkena dampak langsung oleh PT. KLI. Jarak dari tiap titik diberikan 100 - 300 meter. Penentuan jarak dilakukan atas pertimbangan dampak dari kegiatan PT. KLI terhadap ekosistem baik secara langsung maupun tidak langsung. Sehingga diharapkan dengan pemberian jarak tersebut dapat mewakili tiap ekosistem.

\section{Teknik Pengambilan Sampel}

Pengambilan sampel dilakukan secara horizontal pada saat pasang dan surut di tiga lokasi yaitu tambak, muara dan laut. Kemudian pada tiap lokasi ditentukan tiga titik sebagai pengulangan. Dengan cara ini diharapkan dapat memberi kesempatan yang sama pada setiap populasi untuk dijadikan sampel. Pada lokasi yang telah ditentukan, dilakukan pengukuran beberapa parameter fisika (kecerahan, kedalaman, suhu, arus). Parameter kimia yang diukur secara insitu adalah salinitas dan $\mathrm{pH}$, sedangkan pengukuran klorofil-a, nitrat dan fosfat dilakukan di laboratorium.

\section{Analisis Data}

Analisis data dibagi menjadi dua tahapan. Tahap pertama menggunakan analisis of varians (ANOVA) dua arah untuk mengetahui sebaran klorofil-a dan kualitas air. Tahap kedua menggunakan analisis regresi berganda (multiple regression analysis) untuk mengetahui keterkaitan antara klorofil-a dengan kualitas air. Analisis korelasi digunakan untuk mengukur kekuatan hubungan antara dua peubah, yaitu x dan y melalui sebuah bilangan yang disebut koefisien korelasi, dilambangkan dengan r. Nilai r mengukur sejauh mana titik-titik menggerombol sekitar sebuah garis lurus. Bila nilai $\mathrm{r}$ mendekati +1 atau -1 , hubungan antara kedua peubah itu kuat dan dapat dikatakan terdapat korelasi yang tinggi antara keduanya. Akan tetapi bila nilai $r$ mendekati 0 , hubungan linear $x$ dan y sangat lemah atau mungkin tidak ada sama sekali (Hadi, 2004).

Untuk mengetahui hubungan antara sebaran klorofil-a dan kualitas air di setiap lokasi, maka digunakan analisis regresi linier tunggal. Sedangkan untuk mengetahui hubungan antara nitrat, fosfat sekaligus dengan klorofil maka dilakuan analisis regresi linier ganda. Pengolahan data menggunakan software Microsoft Excell dan SPSS. Menurut Sudjana (2005), dalam regresi berganda terdapat peubah bebas yang dihubungkan dengan $\mathrm{Y}$ linier. Jika peubah bebas itu $\mathrm{x} 1, \mathrm{x} 2, \ldots . . \mathrm{x}_{\mathrm{k}}$ dan peubah tak bebasnya itu $\mathrm{Y}$, maka bentuk umum untuk regresi berganda dapat dinyatakan dalam persamaan:

$$
\begin{aligned}
& \text { Keterangan } \\
& \begin{array}{ll}
\mathrm{Y} & =\text { Peubah Tak Bebas/ Terikat (Klorofil-a) } \\
\mathrm{X}_{1}, \mathrm{X}_{2}, \mathrm{X}_{3} & =\text { Peubah Bebas (nitrat, fosfat, kecerahan, suhu, } \\
& \text { arus, salinitas) } \\
= & \text { Intercept } \\
\mathrm{a} & \\
\mathrm{b}_{1}, \mathrm{~b}_{2}, \mathrm{~b}_{3}=\text { slope (kemiringan garis /kurva) }
\end{array}
\end{aligned}
$$

\section{Hipotesis Penelitian}

Hipotesis yang muncul untuk penelitian ini adalah sebagai berikut:

1. Adanya perbedaan antar lokasi dan waktu klorofil-a dengan parameter fisika kimia air $\mathrm{H}_{0}$ : tidak ada beda klorofil-a dan parameter fisika-kimia air antar lokasi maupun waktu $\mathrm{H}_{1}$ : ada beda klorofil-a dan parameter fisika-kimia air antar lokasi maupun waktu

2. Adanya keeratan hubungan antara klorofil-a dengan dengan parameter fisika kimia air $\mathrm{H}_{0}$ : tidak ada keeratan hubungan klorofil-a dan parameter fisika-kimia air $\mathrm{H}_{1}$ : ada keeratan hubungan klorofil-a dan parameter fisika-kimia air

Untuk mengambil keputusan dengan uji statistik yang dilakukan uji $\mathrm{F}$ dengan kaidah sebagai berikut: Statistik F hitung < Statistik F table $(5 \%$ atau $1 \%)$ terima $\mathrm{H}_{0}$ dan tolak $\mathrm{H}_{1}$ Statistik F hitung $>$ Statistik $\mathrm{F}$ table $(5 \%$ atau $1 \%)$ terima $\mathrm{H}_{1}$ dan tolak $\mathrm{H}_{0}$

\section{Pelaksanaan Penelitian}

Penelitian ini dilaksanakan selama tiga bulan (23 Maret - 28 Mei 2013) dengan tiga waktu pengamatan bulan 1, 2 dan 3 dan pengulangan saat kondisi pasang dan surut. Lokasi sampling berada di perairan sekitar PT. Kayu Lapis, Kecamatan Kaliwungu Kabupaten Kendal di tiga ekosistem yaitu ekosistem tambak, ekosistem muara dan ekosistem laut. Lokasi sampling ditentukan setelah adanya survey lokasi. 
Pengambilan sampel air dilakukan di ekosistem yang mendapat pengaruh dari kegiatan PT. KLI. Diperoleh tiga lokasi sekitar PT. KLI yaitu ekosistem laut, ekosistem muara dan ekosistem tambak. Lokasi sampling pada penelitian ini dapat dilihat pada Gambar 1.

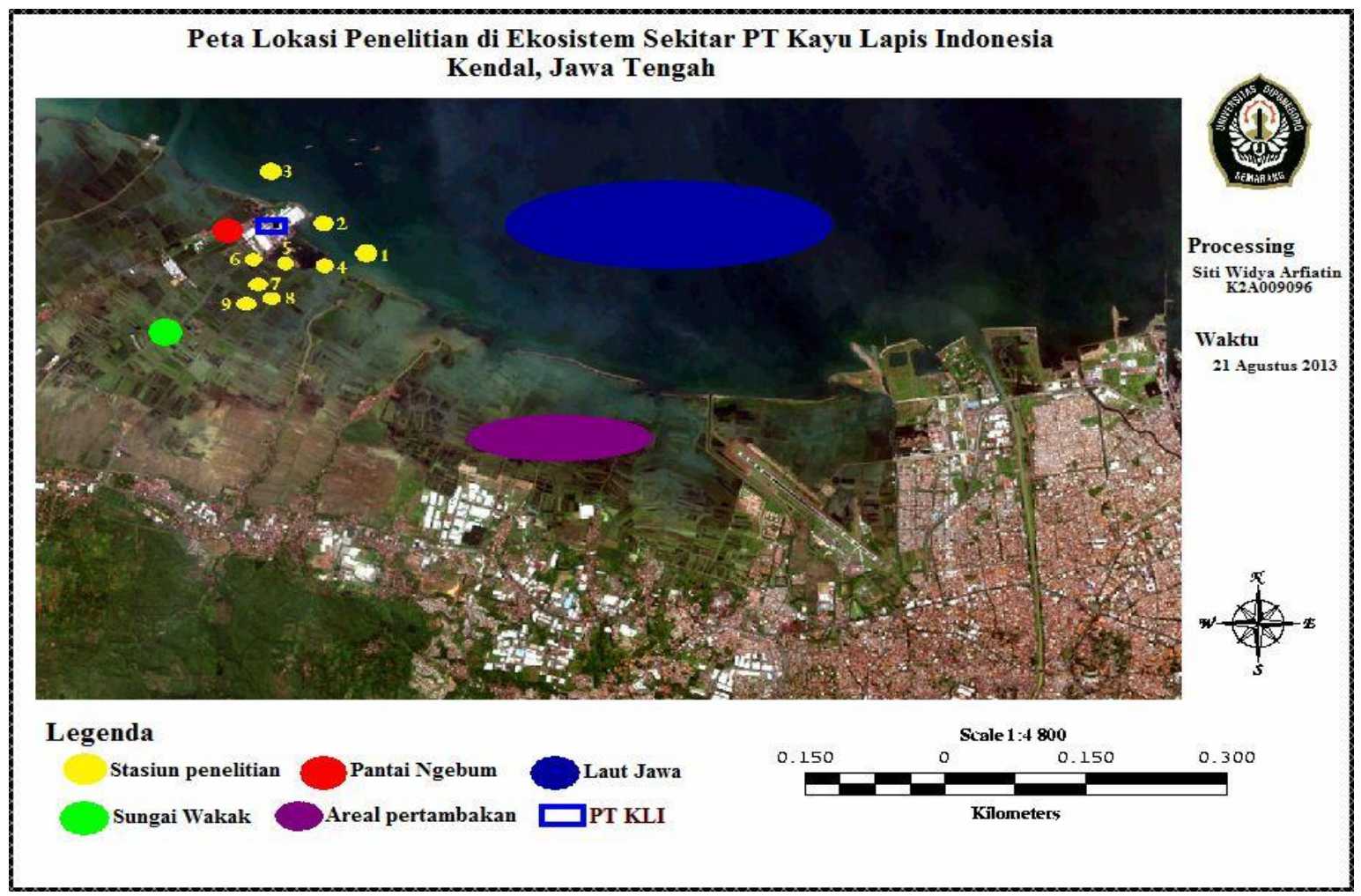

Gambar 1. Peta lokasi penelitian

\section{Hasil dan Pembahasan}

\section{Posisi Geografis Lokasi Penelitian}

Lokasi sampling berada di perairan sekitar PT. Kayu Lapis Indonesia, tepatnya di muara Sungai Wakak. Sungai Wakak terdapat di Desa Mororejo, Kaliwungu Kendal. Menurut informasi warga sekitar, sungai inilah yang mengalami perubahan bentuk karena sengaja dibelokkan oleh PT. Kayu Lapis Indonesia untuk dijadikan log-pond. Terdapat sembilan titik sampling untuk penelitian ini. Masing-masing tiga titik untuk tambak, muara dan Pantai. Setiap titik memiliki jarak 100 - 300 meter ke titik lainnya. Penentuan titik sampling dilakukan berdasarkan pendugaan dampak kegiatan PT. Kayu Lapis Indonesia terhadap perairan tersebut.

\section{Kandungan Klorofil-a}

Hasil analisa laboratorium kandungan klorofil-a tersaji pada grafik berikut:

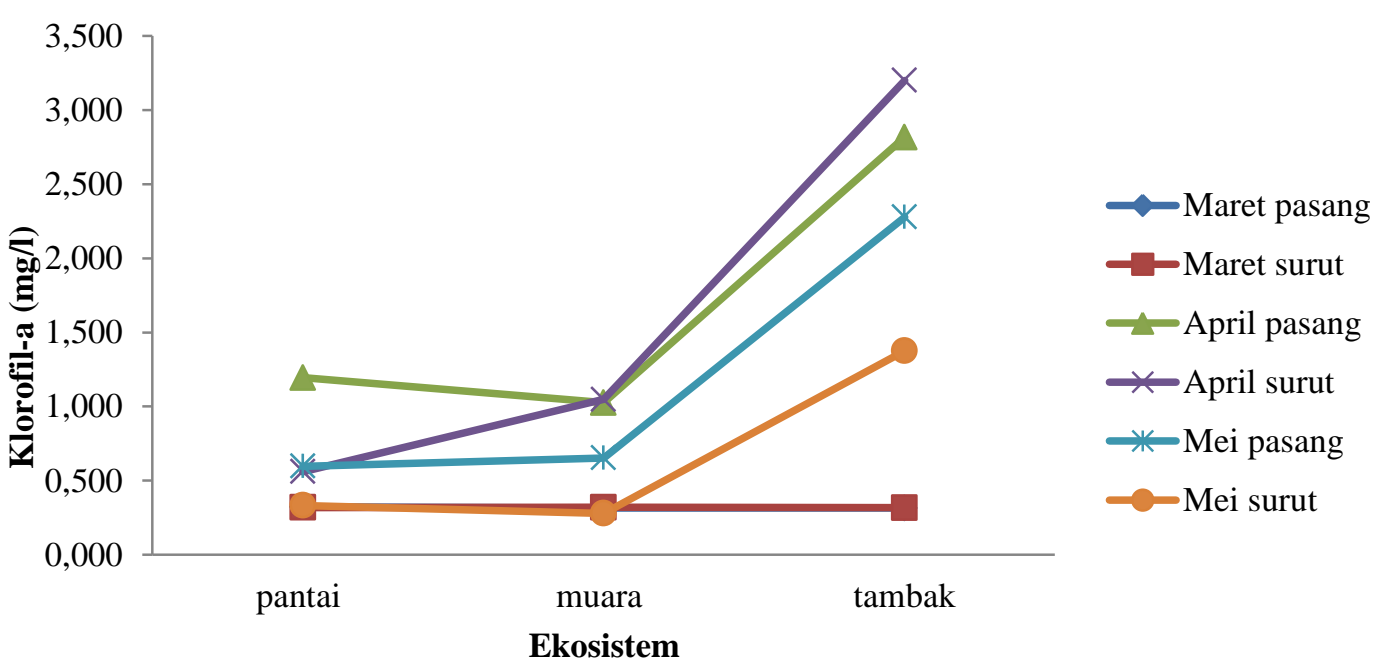

Gambar 2. Sebaran klorofil-a (mg/l) selama penelitian (Maret-Mei 2013) 
Berdasarkan grafik diatas, diperoleh klorofil-a tertinggi pada ekosistem tambak pada bulan Mei saat pasang yakni 3,701 mg/l. Sedangkan klorofil-a terendah terdapat pada ekosistem pantai pada bulan Mei saat pasang yakni $0,275 \mathrm{mg} / \mathrm{l}$. Hal ini diduga pada ekosistem tambak terjadi penambahan nutrient secara langsung dari daratan serta dari pemberian pakan kultivan, sehingga menyebabkan nilai klorofil-a pada ekosistem tambak lebih tinggi dari kedua ekosistem lainnya. Nilai klorofil-a yang diperoleh selama penelitian secara keseluruhan menunjukkan bahwa perairan sekitar PT. KLI berada pada kondisi tingkat kesuburan yang rendah dengan kisaran 0,3-3,7 mg/l. Menurut Hakanson dan Bryann (2008) dalam Faizal et al,. (2011), klorofil-a dengan kisaran nilai $0-4,2$ menunjukkan bahwa perairan tersebut berada pada tingkat kesuburan yang rendah atau oligotrofik.

\section{Kandungan Nitrat}

Hasil analisa laboratorium kandungan nitrat tersaji pada grafik berikut:
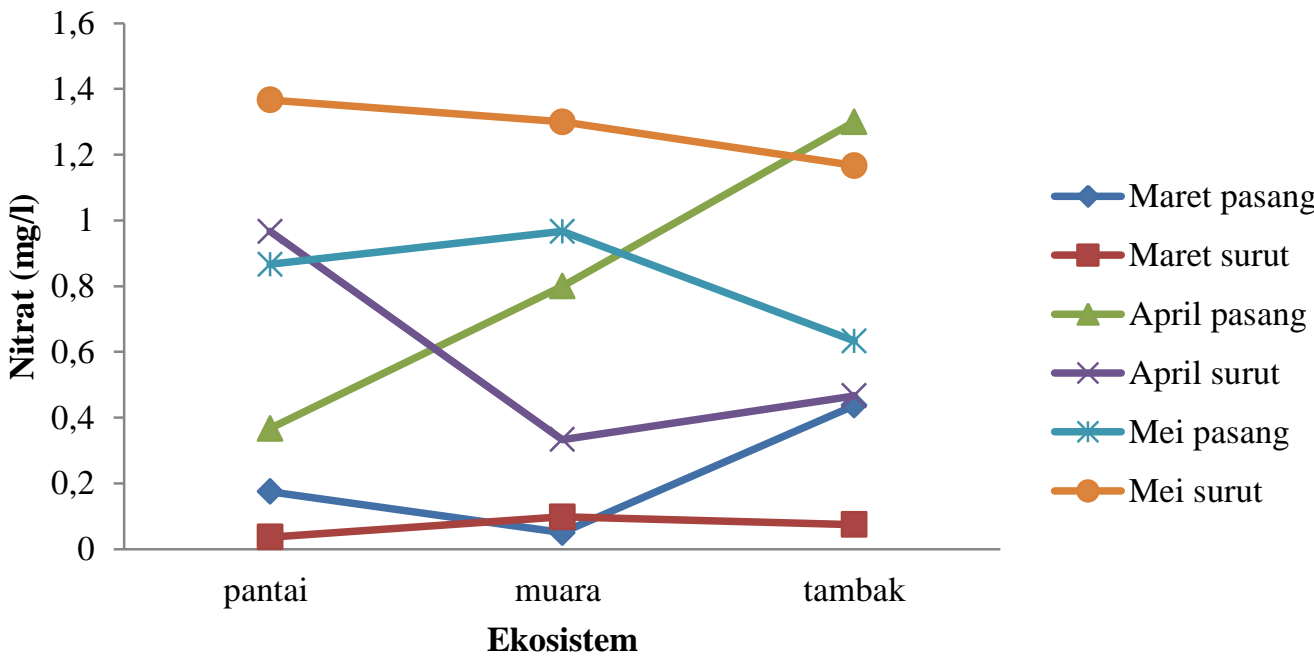

Gambar 3. Sebaran nitrat (mg/l) selama penelitian (Maret-Mei 2013)

Berdasarkan Gambar 3, kandungan nitrat tertinggi terjadi pada ekosistem pantai yakni 1,367 mg/l pada bulan Mei saat surut. Sedangkan kandungan nitrat terrendah pada ekosistem pantai bulan Maret saat surut yakni $0,03 \mathrm{mg} / \mathrm{l}$. Tingginya kandungan nitrat pada ekosistem pantai diduga titik 1,2 dan 3 mendapat pengaruh pasang surut serta arus yang cukup kuat sehingga menyebabkan terjadinya peningkatan nitrat pada bulan Mei. Nitrat yang diperoleh selama penelitian menunjukkan bahwa secara umum perairan tersebut berada pada tingkat kesuburan yang rendah yaitu berada pada kisaran $0,04-1,36 \mathrm{mg} / \mathrm{l}$. Hakanson dan Bryann (2008) dalam Faizal et al.,(2011) menyatakan bahwa kondisi perairan oligotrofik atau kesuburan rendah memiliki kisaran nitrat pada $0,3-0,9 \mathrm{mg} / \mathrm{l}$.

\section{Kandungan Fosfat}

Hasil analisa laboratorium kandungan fosfat tersaji pada grafik berikut:
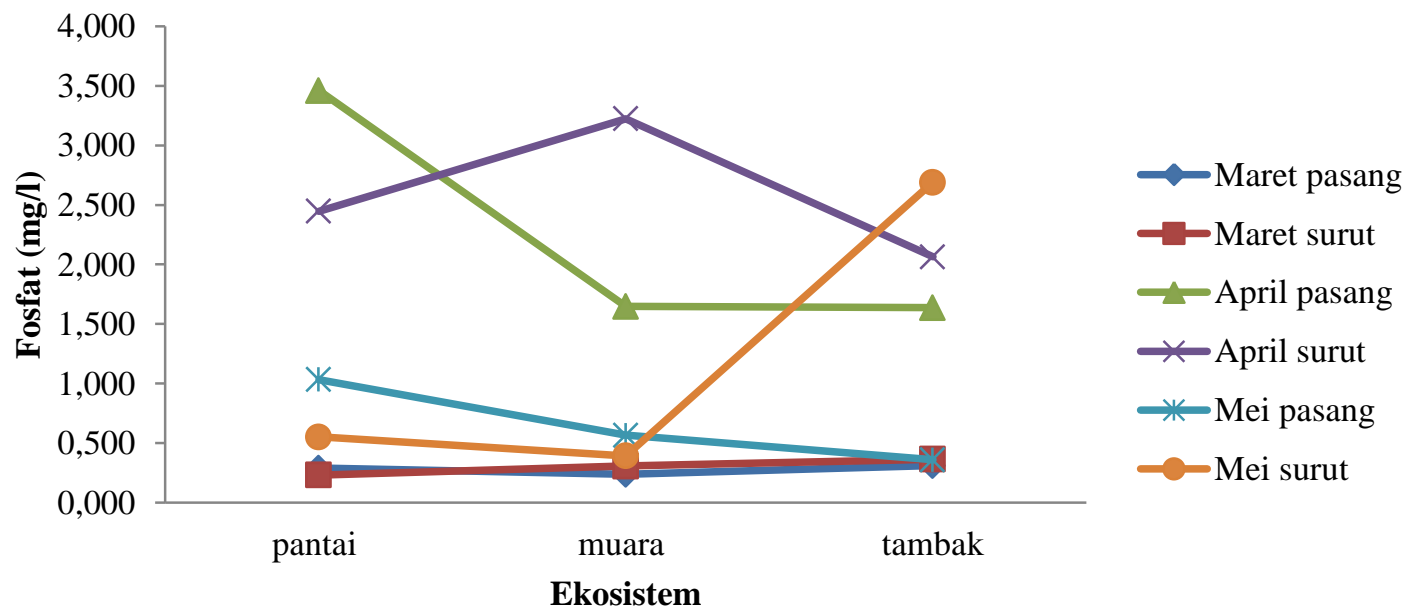

Gambar 4. Sebaran fosfat (mg/l) selama penelitian (Maret-Mei 2013) 
Berdasarkan Gambar 4, kandungan fosfat tertinggi terjadi pada ekosistem pantai pada bulan April saat pasang yakni $3,46 \mathrm{mg} / \mathrm{l}$. Sedangkan kandungan fosfat rendah terjadi pada ekosistem pantai pada bulan Maret saat surut yakni $0,233 \mathrm{mg} / \mathrm{l}$. Fluktuasi fosfat yang terjadi di ekosistem pantai disebabkan parameter oceanografi. Sama halnya dengan fluktuasi yang terjadi pada nitrat. Tingginya kandungan fosfat pada ekosistem pantai dipengaruhi oleh pasang surut serta arah angin dan kecepatan arus. Periode pasang pada bulan April lebih lama dibanding periode surut, sehingga fosfat yang terbawa dari daratan terakumulasi di ekosistem pantai. Konsentrasi fosfat tertinggi diperoleh pada ekosistem pantai dan terrendah terjadi pada ekosistem muara. Hal ini terjadi karena ekosistem pantai mendapat pengaruh dari kegiatan PT. KLI terutama lalu lalang kapal pengangkut kayu dari kapal tongkang. Menurut Wattayakorn (1988) dalam Muchtar (2002), kandungan fosfat dan nitrat di daerah estuari selain berasal dari perairan itu sendiri juga tergantung kepada keadaan sekelilingnya.

\section{Parameter Fisika-Kimia Air}

\section{a. Suhu air}

Berdasarkan hasil penelitian, diperoleh suhu yang relatif seragam baik antar ekosistem maupun antar waktu penelitian. Suhu pada ekosistem pantai berkisar antara $31-34{ }^{0} \mathrm{C}$ sedangkan pada ekosistem muara berkisar antara $30-33{ }^{\circ} \mathrm{C}$ dan di ekosistem tambak berkisar antara $30-34{ }^{\circ} \mathrm{C}$. Parameter oceanografi pasang surut dalam hal ini tidak memberikan pengaruh yang signifikan terhadap fluktuasi suhu di lokasi penelitian. Suhu air yang diperoleh saat penelitian menunjukkan bahwa perairan pada tiap ekosistem masih berada pada keadaan normal untuk suatu perairan dan masih dapat digunakan untuk kehidupan organisme perairan. Effendi (2003), kisaran optimum suhu yang dapat ditolerir oleh organisme perairan yaitu berada pada 20 - 30 atau $30-35{ }^{0} \mathrm{C}$.

\section{b. Kecerahan}

Berdasarkan hasil penelitian, diperoleh kecerahan tertinggi pada ekosistem pantai. Kecerahan pada ekosistem pantai berkisar antara 38,33 - 90,33 cm, sedangkan pada ekosistem muara berkisar antara 29,50 $58 \mathrm{~cm}$ dan pada ekosistem tambak berkisar antara $21-35,83 \mathrm{~cm}$. Tingginya kecerahan di ekosistem tambak pada bulan Maret saat surut disebabkan pengukuran kecerahan tidak dilakukan pada saat surut terendah tetapi saat surut menjelang pasang sehingga kecerahannya cukup tinggi karena massa air mulai meningkat kembali. Berdasarkan pengamatan di lapangan menunjukkan bahwa pasang surut di lokasi penelitian bertipe pasang surut campuran condong ke harian ganda. Dari data kecerahan yang diperoleh saat penelitian menunjukkan bahwa perairan sekitar PT Kayu Lapis Indonesia masih dapat digunakan untuk kehidupan organisme perairan. Menurut Effendi (2003), nilai kecerahan sangat dipengaruhi oleh keadaan cuaca, waktu pengukuran, kekeruhan, dan padatan tersuspensi serta ketelitian orang yang melakukan pengukuran.

c. Arus

Berdasarkan hasil penelitian, diperoleh hasil pengukuran kecepatan arus tertinggi pada ekosistem pantai yakni berkisar antara $0,53-1,19 \mathrm{~m} / \mathrm{s}$ saat surut dan $1,16-1,42 \mathrm{~m} / \mathrm{s}$ saat pasang. Hal ini terjadi karena ekosistem pantai mendapat pengaruh pasang surut yang lebih besar dibanding ekosistem muara dan tambak. Parameter oceanografi lainnya seperti arah angin dan gelombang juga mempengaruhi tingginya kecepatan arus pada ekosistem pantai. Selain itu, kecepatan arus sangat dipengaruhi arah angin dan musim. Angin pada bulan Maret menuju ke arah timur saat pasang sedangkan saat surut menuju ke arah barat. Angin pada bulan April dan Mei mulai menuju ke arah barat saat pasang dan saat surut menuju ke arah timur. Arus merupakan gerakan mengalir suatu massa air yang dapat disebabkan oleh tiupan angin, perbedaan dalam densitas air pantai, maupun oleh gerakan bergelombang panjang, misalnya pasang surut. Di perairan terbuka, arah dan kekuatan arus di lapisan permukaan sangat banyak ditentukan oleh angin (Nontji, 1993).

\section{d. Salinitas}

Berdasarkan Tabel 11, diperoleh salinitas tertinggi pada ekosistem pantai yakni 34 \%o dan salinitas terrendah terdapat pada ekosistem tambak yakni $18 \%$. Salinitas yang diperoleh pada ekosistem tambak selama penelitian dikategorikan cukup tinggi karena tambak disekitar perairan PT KLI masih mendapat pengaruh yang cukup besar dari air laut. Salinitas yang diperoleh selama penelitian menunjukkan bahwa perairan sekitar PT KLI masih dapat digunakan untuk kehidupan organisme perairan. Namun, jika dilihat dari kandungan klorofil-a dan nutriennya, perairan sekitar PT KLI dikategorikan dalam perairan dengan kesuburan yang rendah atau oligotrofik.

\section{Analisis Data}

Analisis Ragam (ANOVA)

Hasil uji beda nyata tersaji pada tabel berikut :

Tabel 1. Uji beda nyata antar stasiun (Pantai, Muara, Tambak)

\begin{tabular}{cccc}
\hline No & Variabel & Pasang & Surut \\
\hline 1. & Klorofil-a & TB & TB \\
2. & Nitrat & TB & TB \\
3. & Fosfat & TB & TB \\
\hline
\end{tabular}

Keterangan: Hasil penelitian (TB: tidak beda, BN: beda nyata) 
Berdasarkan Tabel 1, diperoleh hasil tidak beda nyata antar stasiun terhadap variabel klorofil-a, nitrat dan fosfat baik pasang dan surut. Berdasarkan analisis ragam diperoleh Fhitung sebesar 2,41672 dan Ftabel sebesar 2,5911. Hasil tersebut menunjukkan bahwa Fhitung lebih kecil dari Ftabel maka terima Ho yang berarti tidak terjadi perbedaan sebaran klorofil-a antar stasiun saat pasang. Analisis ragam terhadap variabel klorofil-a saat surut diperoleh Fhitung sebesar 1,26972 dan Ftabel sebesar 2,5911. Hasil tersebut menunjukkan bahwa Fhitung lebih kecil dari Ftabel maka kembali terima Ho yang berarti tidak terjadi perbedaan terhadap sebaran klorofil-a antar stasiun saat surut.

Hasil uji beda nyata terhadap variabel nitrat diperoleh Fhitung sebesar 1,80029 dan Ftabel sebesar 2,5911. Hasil tersebut menunjukkan bahwa Fhitung lebih kecil dari Ftabel maka terima Ho yang berarti tidak terjadi perbedaan sebaran nitrat antar stasiun saat pasang. Analisis ragam terhadap variabel nitrat saat surut diperoleh Fhitung sebesar 1,83516 dan Ftabel sebesar 2,5911. Hasil tersebut menunjukkan bahwa Fhitung lebih kecil dari Ftabel maka kembali terima Ho yang berarti tidak terjadi perbedaan terhadap sebaran nitrat antar stasiun saat surut.

Hasil uji beda nyata terhadap variabel fosfat diperoleh Fhitung sebesar 1,674975 dan Ftabel sebesar 2,5911. Hasil tersebut menunjukkan bahwa Fhitung lebih kecil dari Ftabel maka terima Ho yang berarti tidak terjadi perbedaan sebaran fosfat antar stasiun saat pasang. Analisis ragam terhadap variabel fosfat saat surut diperoleh Fhitung sebesar 0,47245 dan Ftabel sebesar 2,5911. Hasil tersebut menunjukkan bahwa Fhitung lebih kecil dari Ftabel maka kembali terima Ho yang berarti tidak terjadi perbedaan terhadap sebaran fosfat antar stasiun saat surut.

Tabel 2. Uji beda nyata antar waktu (Maret, April, Mei)

\begin{tabular}{cccc}
\hline No & Variabel & Pasang & Surut \\
\hline 1. & Klorofil-a & BN & BB \\
2. & Nitrat & BN & BN \\
3. & Fosfat & BN & BN \\
\hline
\end{tabular}

Keterangan: Hasil penelitian (TB: tidak beda, BN: beda nyata)

Berdasarkan Tabel 2, diperoleh hasil beda nyata antar waktu terhadap variabel nitrat dan fosfat baik pasang dan surut sedangkan terhadap variabel klorofil-a terjadi perbedaan secara nyata hanya saat pasang.

Analisis ragam diperoleh Fhitung sebesar 4,65165 dan Ftabel sebesar 3,63372. Hasil tersebut menunjukkan bahwa Fhitung lebih besar dari Ftabel maka tolak Ho yang berarti terjadi perbedaan secara nyata terhadap sebaran klorofil-a antar waktu saat pasang. Analisis ragam terhadap variabel klorofil-a saat surut diperoleh Fhitung sebesar 3,07691 dan Ftabel sebesar 3,63372. Hasil tersebut menunjukkan bahwa Fhitung lebih kecil dari Ftabel maka terima Ho yang berarti tidak terjadi perbedaan terhadap sebaran klorofil-a antar waktu saat surut.

Hasil uji beda nyata terhadap variabel nitrat diperoleh Fhitung sebesar 6,3131dan Ftabel sebesar 3,63372. Hasil tersebut menunjukkan bahwa Fhitung lebih besar dari Ftabel maka tolak Ho yang berarti terjadi perbedaan secara nyata terhadap sebaran nitrat antar waktu pada saat pasang. Analisis ragam terhadap variabel nitrat saat surut diperoleh Fhitung sebesar 53,1931 dan Ftabel sebesar 3,63372. Hasil tersebut menunjukkan bahwa Fhitung lebih besar dari Ftabel maka tolak Ho yang berarti terjadi perbedaan secara nyata terhadap sebaran nitrat antar waktu pada saat surut.

Hasil uji beda nyata terhadap variabel fosfat diperoleh Fhitung sebesar 26,2622 dan Ftabel sebesar 3,63372. Hasil tersebut menunjukkan bahwa Fhitung lebih besar dari Ftabel maka tolak Ho yang berarti terjadi perbedaan secara nyata terhadap sebaran fosfat antar waktu pada saat pasang. Analisis ragam terhadap variabel fosfat saat surut diperoleh Fhitung sebesar 14,8248 dan Ftabel sebesar 3,63372. Hasil tersebut menunjukkan bahwa Fhitung lebih besar dari Ftabel maka kembali tolak Ho yang berarti terjadi perbedaan secara terhadap sebaran fosfat antar waktu saat surut.

\section{Analisis Regresi dan Korelasi}

Analisis regresi ganda bertujuan untuk mengetahui hubungan antara klorofil-a dengan parameter fisika-kimia air pada tiap ekosistem yaitu pantai, muara dan tambak.

Tabel 3. Hasil Analisis Korelasi Regresi Ganda (Multiple Regression) klorofil-a dengan parameter fisikakimia air $\left(\mathrm{X}_{1}\right.$ : Nitrat $; \mathrm{X}_{2}$ : Fosfat $; \mathrm{X}_{3}$ : Kecerahan $)$

\begin{tabular}{cccc}
\hline Ekosistem & Persamaan Multiple Regression & r & $\mathbf{R}^{2}$ \\
\hline Pantai & $\mathrm{Y}=0,378-0,297 \mathrm{x}_{1}+0,281 \mathrm{x}_{2}-0,002 \mathrm{x}_{3}$ & 0.959 & 0.920 \\
Muara & $\mathrm{Y}=0,089-0,016 \mathrm{x}_{1}+0,246 \mathrm{x}_{2}+0,005 \mathrm{x}_{3}$ & 0.757 & 0.573 \\
Tambak & $\mathrm{Y}=-3,663+2,031 \mathrm{x}_{1}+1,046 \mathrm{x}_{2}+0,11 \mathrm{x}_{3}$ & 0.601 & 0.361 \\
\hline
\end{tabular}

Keterangan : $\alpha=0.05$ dan significant value

Berdasarkan Tabel 3, diperoleh hasil analisis korelasi regresi berganda yang menunjukkan bahwa klorofil-a dipengaruhi oleh nitrat, fosfat dan kecerahan. 
Hasil regresi ganda (multiple regression) terhadap klorofil-a $(\mathrm{y})$, nitrat $\left(\mathrm{x}_{1}\right)$, fosfat $\left(\mathrm{x}_{2}\right)$ dan kecerahan $\left(\mathrm{x}_{3}\right)$ pada ekosistem pantai menunjukkan nilai koefisien korelasi (r) sebesar 0,95 yang berarti memiliki hubungan yang kuat antar variabel $\mathrm{x}$ dan $\mathrm{y}$. Hasil analisis ganda pada ekosistem muara menunjukkan nilai koefisien korelasi (r) sebesar 0,75 yang berarti memiliki hubungan yang cukup kuat antar klorofil-a dengan nitrat, fosfat dan kecerahan. Sedangkan pada ekosistem tambak, diperoleh nilai koefisien korelasi 0,60 yang brarti klorofil-a dengan nitrat, fosfat dan kecerahan memiliki hubungan yang agak rendah. Menurut Hadi (2004), koefisien korelasi antara 0 sampai +1 menunjukkan korelasi yang positif sedangkan dari -1 sampai 0 menunjukkan korelasi yang negatif.

Analisis regresi ganda terhadap klorofil-a $(\mathrm{y})$, nitrat $\left(\mathrm{x}_{1}\right)$, fosfat $\left(\mathrm{x}_{2}\right)$ dan kecerahan $\left(\mathrm{x}_{3}\right)$ menghasilkan koefisien determinasi $\left(\mathrm{R}^{2}\right)$ yang merupakan kuadrat koefisien korelasi yang menunjukkan besarnya ragam variabel y (tergantung) yang dapat dijelaskan oleh variabel $\mathrm{x}$ (bebas). Koefisien determinasi $\left(\mathrm{R}^{2}\right)$ pada ekosistem pantai sebesar 0,92 yang berarti sebesar $92 \%$ variabel $\mathrm{x}$ mempengaruhi variabel $\mathrm{y}$. Koefisien determinasi $\left(\mathrm{R}^{2}\right)$ pada ekosistem muara sebesar 0,57 yang berarti sebesar $57 \%$ variabel $\mathrm{x}$ mempengaruhi variabel y. Sedangkan Koefisien determinasi $\left(R^{2}\right)$ pada ekosistem tambak sebesar 0,36 yang berarti sebesar $36 \%$ variabel x mempengaruhi variabel y.

\section{Kesimpulan}

Kesimpulan yang diperoleh dari penelitian ini adalah sebagai berikut :

1. Sebaran spasial klorofil-a dan kualitas air menunjukkan tidak terjadi perbedaan secara nyata, diperoleh Fhitung lebih kecil dari Ftabel yang berarti terima Ho sedangkan sebaran temporal klorofil-a dan kualitas air menunjukkan terjadi perbedaan secara nyata antar waktu, diperoleh Fhitung lebih besar dari Ftabel yang berarti tolak Ho.

2. Tingkat kesuburan ekosistem perairan sekitar PT. Kayu Lapis Indonesia termasuk dalam kategori kesuburan yang rendah atau oligotrofik dengan nilai klorofil dan kualitas air $<3$. Hal ini ditunjukkan dengan hubungan yang kuat antar klorofil- $\alpha$ dengan variabel nitrat, fosfat dan kecerahan yang terjadi hanya pada ekosistem pantai dengan nilai koefisien korelasi (r) terbesar 0,95 dan koefisien determinasi $\left(\mathrm{R}^{2}\right)$ sebesar 0,92 yang berarti sebesar $92 \%$ variabel $\mathrm{X}$ (nitrat, fosfat, kecerahan) mempengaruhi variabel Y (klorofil- $\alpha$ ). Sedangkan pada ekosistem muara dan tambak terjadi hubungan yang rendah.

\section{Ucapan Terima Kasih}

Ucapan terima kasih ditujukan kepada Bapak Mukaror yang telah membantu peneliti selama kegiatan penelitian. Ucapan terima kasih ditujukan pula kepada Dr. Ir. Max Rudolf Muskananfola, M.Sc dan Dr. Ir. Agung Suryanto, MS atas bimbingannya dalam penyusunan penelitian ini.

\section{Daftar Pustaka}

Astuti, P. 2008. Wilayah Kesuburan. FMIPA: Universitas Indonesia.

Dahuri, R., J. Rais, S.P. Ginting dan M.J. Sitepu. 1996. Pengelolaan Sumber Daya Wilayah Pesisir dan Lautan Secara Terpadu. Pradnya Paramita: Jakarta. XXIV; 305 hlm; 26 cm; ISBN979-408-381-X.

Effendi, H. 2003. Telaah Kualitas Air Bagi Pengelolaan Sumber Daya Dan Lingkungan Perairan. Kanisius, Yogyakarta.

Faizal, A. J. Jompa, N. Nessa dan C. Rani. 2011. Dinamika Spasio-Temporal Tingkat Kesuburan Perairan di Kepulauan Spermonde, Sulawesi Selatan. FKIP Universitas Hasanuddin: Makassar.

Febrianty, E. 2011. Produktivitas Alga Hydrodictyon pada Sistem Perairan Tertutup (Closed System). Skripsi. IPB: Bogor.

Hadi, S. 2004. Statistik (Jilid 2). Andi: Yogyakarta. 172 hlm.

Muchtar, M. 2002. Distribusi Fosfat dan Nitrat di Perairan Kalimantan Timur. Pusat Penelitian Oseanografi. LIPI, Indonesia. ISBN 979-8105-92-3.

Nontji, A. 1993. Laut Nusantara. Cetakan ke-3. Penerbit Djambatan, Jakarta: 367 hal.

Purwanto, E. A. dan Dyah, R. S. 2007. Metode Penelitian Kuantitatif untuk Administrasi Publik dan Masalah-masalah Sosial. Gava Media: Yogyakarta.

Sanusi, H.S. 2004. Karakteristik Kimiawi dan Kesuburan Perairan Teluk Pelanuhan Ratu pada Musim Barat dan Timur. Jurnal Ilmu-Ilmu Perairan dan Perikanan Indonesia. Jilid 11 Nomor 2: 93-100.

Sudjana. 2005. Metoda Statistika Edisi Ke 6. Tarsito: Bandung. 508 hlm. ASBN 979-9185-37-8

Sukmadinata, N.S. 2007. Pengembangan Kurikulum Teori dan Praktek . PT. Remaja Rosdakarya : Bandung. 